\title{
Sweet cherry: composition, postharvest preservation, processing and trends for its future use
}

Suwimol Chockchaisawasdee, John, B Golding, Quan V. Vuong Konstantinos Papoutsis and Costas E. Stathopoulos

This is the accepted manuscript $($ 2016, Elsevier Licensed under the Creative Commons Attribution-NonCommercialNoDerivatives 4.0 International (CC BY-NC-ND 4.0) http://creativecommons.org/licenses/by-nc-nd/4.0/ $(\mathrm{cc})$ EY-No-ND

The published article is available from doi: http://dx.doi.org/10.1016/i.tifs.2016.07.002 
Sweet cherry: Composition, postharvest preservation, processing and trends for its future use

Suwimol Chockchaisawasdee ${ }^{a^{*}}$, John B. Golding ${ }^{\text {a,b }}$, Quan V. Vuong ${ }^{\text {a }}$, Konstantinos Papoutsis $^{\mathrm{a}}$, and Costas E. Stathopoulos ${ }^{\mathrm{c}}$

${ }^{a}$ School of Environmental and Life Sciences, The University of Newcastle PO Box 127 Ourimbah, NSW 2258, Australia

${ }^{\mathrm{b}}$ NSW Department of Primary Industries, Locked Bag 26 Gosford, NSW 2250, Australia

${ }^{c}$ School of Science, Engineering and Technology, University of Abertay, Dundee DD1 1HG, UK

* Corresponding author

Email address: $\quad$ Suwimol.Chockchaisawasdee@newcastle.edu.au

E-mail addresses of co-authors:

JB Golding: $\quad$ John.Golding@ dpi.nsw.gov.au

QV Vuong: $\quad$ Vanquan.Vuong@ @ newcastle.edu.au

K Papoutsis: $\quad$ Konstantinos.Papoutsis@uon.edu.au

CE Stathopoulos: C.Stathopoulos@ abertay.ac.uk 


\section{Abstract}

\section{Background}

Sweet cherries (Prunus avium L.) are a nutritious fruit which are rich in polyphenols and have high antioxidant potential. Most sweet cherries are consumed fresh and a small proportion of the total sweet cherries production is value added to make processed food products. Sweet cherries are highly perishable fruit with a short harvest season, therefore extensive preservation and processing methods have been developed for the extension of their shelf-life and distribution of their products.

\section{Scope and Approach}

In this review, the main physicochemical properties of sweet cherries, as well as bioactive components and their determination methods are described. The study emphasises the recent progress of postharvest technology, such as controlled/modified atmosphere storage, edible coatings, irradiation, and biological control agents, to maintain sweet cherries for the fresh market. Valorisations of second-grade sweet cherries, as well as trends for the diversification of cherry products for future studies are also discussed.

\section{Key Findings and Conclusions}

Sweet cherry fruit have a short harvest period and marketing window. The major loss in quality after harvest include moisture loss, softening, decay and stem browning. Without compromising their eating quality, the extension in fruit quality and shelf-life for sweet cherries is feasible by means of combination of good handling practice and applications of appropriate postharvest technology. With the drive of health-food sector, the potential of using second class cherries including cherry stems as a source of bioactive compound extraction is high, as cherry fruit is well-known for being rich in health-promoting components. 
Keywords: Prunus avium; postharvest technology; sweet cherry products; anthocyanins; phenolic compounds; value adding

\section{Highlights}

- Physicochemical and bioactive components in sweet cherries

- Progress in postharvest applications for sweet cherries

- Novel processing processes for cherry products

- Future trends of valorisation of sweet cherry fruits and stems 


\section{Introduction}

Cherries are thought to be native to Europe and western Asia and are now grown widely around the world (Webster \& Looney, 1996; Iezzoni, 2008). Cherries are within the Rosaceae family and belong to the genus Prunus, subspecies Cerasus and section Eucerasus. There are three main species of cherry fruits referenced in this section; sweet (P. avium), and tart or sour (P. cerasus), and ground (P. fruticosa Pall.) cherries. Among the three species, of global trading importance are sweet and tart cherries (Iezzoni, 2008). Commercial cultivation of sweet cherry is generally more difficult and expensive than tart cherry as high levels of care must be taken throughout the supply chain to achieve premium quality fruit for serving in the fresh market (Looney \& Jackson, 2011; Sredojević, Milić, \& Jeločnik, 2011).

The basic chromosome number of Prunus (section Eucerasus) is $x=8$. Sweet cherry is diploid $(2 \mathrm{n}=16)$ while tart cherry is tetraploid $(2 \mathrm{n}=32)$ (Iezzoni, 2008). A botanical feature which differentiate sweet from sour cherries is the size distribution of subepidermal cells: in tart cherry are even, while those in sweet cherry are not. However, the main difference in physiochemical properties of sweet and tart cherry are fruit size, level of pectic substances, the ratio of soluble solids content (SSC, or total soluble solids (TSS)) to titratable acidity (TA), and the composition of anthocyanins. Unlike the tart cherry fruits, which have more sour taste due to higher levels of organic acids (8-20\% SSC, $1.5-1.8 \%$ TA), sweet cherries have higher levels of sugar and lower levels of TA (13-25\% SSC, $0.4-1.5 \%$ TA) (Girard \& Kopp, 1998; McLellan \& Padilla-Zakour, 2004). The SSC/TA ratio has an impact on the perception of sweetness and flavour (Crisosto, Crisosto, \& Metheney, 2003). Kappel, Fisher-Fleming, \& Hogue (1996) reported that the SSC/TA ratio yielding the highest sensorial appreciation was between 1.5 and 2. The major anthocyanin compound found in sweet cherry is cyanidin 3-rutinoside whilst in tart cherry is cyanidin 3-glucosylrutinoside (Kim, Heo, Kim, Yang, \& Lee, 2005). Tart cherries are generally smaller in size but contain 
higher amounts of pectic substances than those in sweet cherry (Cao et al., 2015). Tart cherries are generally grown exclusively for processing, while sweet cherries are mainly grown for the fresh market.

This review will focus on the use of fresh sweet cherry for fresh and processing markets. It provides comprehensive details on the important nutritional components and their analysis methods in sweet cherries, trends of postharvest research (such as controlled/modified atmosphere storage, edible coatings, irradiation, and biological control agents), processing of sweet cherries, as well as trends for the diversification of cherry products for future studies.

\section{World production, cultivars, and eating quality attributes of sweet cherries}

Sweet cherry is an important horticultural trading around the world (Webster \& Looney, 1996). The quantity of global cherry exports increased from 145 thousand tons in 2000 to 376 thousand tons in 2011, with the USA, Turkey, Chile, and Spain as the main exporters (FAOSTAT, 2015). There are hundreds of commercial sweet cherry cultivars, but there are generally only a number of predominate cultivars in any given country or region. Cherries are harvested in the summer periods, where in general early-ripening cultivars predominate at lower latitudes, while late-maturing cultivars are grown in higher latitudes, such as western Canada and Norway (Looney \& Jackson, 2011). Fresh sweet cherries are now routinely marketed across the world. Different cultivars meet the market demands in each overseas market. Important considerations of each export cultivar include harvest time, suitability for long-distant shipping, and fruit quality and eating attributes appropriate for each market. However, cultivars yielding high quality fruit which are less prone to fruit defects during growth and after harvest are always highly sought after. Current important cherry cultivars include 'Alex', 'Attika', 'Bing', 'Brooks', 'Burlat', 'Chelan', 'Hedelfingen', 
'Kordia', 'Lambert', 'Lapins', 'Rainier', 'Regina', 'Skeena', 'Sonata', 'Staccato', 'Stella', 'Sweetheart', 'Techlovan', 'Tulare' and 'Van' (Schuster, 2012). However the breeding of new cherry cultivars with superior pre- and postharvest traits are being actively researched. Schuster (2012) summarised an update of the S-genotype of 734 sweet cherries, which included 51 new cultivars in addition to the previously published data.

The quality of sweet cherries in the market is usually determined by fruit size, skin colour, flavour, sweetness, sourness, firmness and stem colour, as these attributes have been found to be closely related to consumers' acceptability and market prices (Dever, MacDonald, Cliff, \& Lane, 1996). Indeed many studies have confirmed correlations between physicochemical properties of sweet cherries (weight, appearances of skin and stem, SSC, TA, SSC/TA ratio, firmness) and cherry fruit acceptability by taste panellists and consumers (Kappel et al., 1996; Dever et al., 1996; Crisosto et al., 2003). In general, consumers are firstly attracted to the appearance of cherries; where fruit which have bright and shiny skin, absence of defects and flaws, intensity and homogeneity of skin colour, appearance of stem, and good fruit size are highly prized. Taste, texture and flavour are generally second decisive criteria in quality appreciation. Each market has its own preferences and opinions on what constitutes a high quality cherry. Crisosto et al. (2003) showed that for 'Brooks' and 'Bing' cherries, need to be a full bright red or dark mahogany skin colour, respectively with a minimum SSC of $16.0 \%$ Brix to satisfy the majority of American consumers.

\section{Composition of sweet cherries}

Botanically, cherry fruit are classified as a fleshy drupe with a central stony-hard seed surrounded with fleshy fruit, which contains most of the nutrients and bioactive components. Sweet cherry fruits have a glossy bright appearance with a thin skin and can either be described as dark red, red, blush, or white. The development of chromatic characteristics 
depends on the cultivars, growing conditions, ripeness stage, and storage conditions (Gonçalves et al., 2007). Sweet cherry fruits are considered highly nutritious fruits where they have significant levels of important nutrients and bioactive components, including glucose, fructose, vitamin C, anthocyanins, quercetin, flavan-3-ols, flavanols and hydroxycinnamate (Gao \& Mazza, 1995). However numerous studies have demonstrated that the levels of these compounds vary depending on a range of preharvest and postharvest factors such as cultivar, stages of ripeness, growing conditions, pre- and postharvest treatments (Cao et al., 2015; Esti, Cinquanta, Sinesio, Moneta, \& Matteo, 2002; Gonçalves et al., 2007; Serrano, Guillén, Martínez-Romero, Castillo, \& Valero, 2005; Usenik, Fabčič, \& Štampar, 2008).

Sweet cherry fruits also contain relatively high levels of bioactive components. There have been numerous in vitro and in vivo studies which have linked these bioactive components in cherries with various health benefits (McCune, Kubota, Stendell-Hollis, \& Thomson,, 2011; Del Rio, Costa, Lean, \& Crozier, 2010; Tomás-Barberán \& Andrés- Lacueva, 2012; Wang \& Stoner, 2008).

\subsection{Nutrient components}

Sweet cherry fruit are prized for their excellent taste and nutritious nature. A summary of the organoleptic attributes (SSC, TA, anthocyanin, total phenolic content (TPC)) in a range of sweet cherry cultivars is presented in Table 1 and demonstrates the range and diversity of cherry quality parameters in important cherry cultivars around the world.

\subsubsection{Sugars}

Sugars play an essential role in quality of sweet cherry fruits as they are balanced with acid in the fruit to contribute to flavour. In sweet cherries, the level of sugars can be as high 
as $25 \mathrm{~g} / 100 \mathrm{~g}$ of fruit (Girard \& Kopp, 1998). Five different types of sugars are normally found in sweet cherries, glucose, sucrose, fructose, maltose, and sorbitol. However the main sugars found in sweet cherries are glucose and fructose which account for approximately $90 \%$ of total sugars of the fruits (Usenik et al., 2008). The levels of these different sugars vary depend on the cultivar, agronomic factors, environmental conditions and the stage of development and ripening (Ballistreri et al. 2013; Serrano, Guillén, et al., 2005; Usenik et al., 2008; Usenik, Stampar, Petkovsek, \& Kastelec, 2015). A study on the changes of sugar levels the cherry cultivar 'Marvin-Niram', during 14 different stages of maturity (in accordance with homogenous size and colour), showed that the levels of glucose and fructose steadily increased during growth and development (Serrano, Guillén, et al., 2005).

The levels of sugars in the fresh cherry fruit have been shown to have a strong relationship with the acceptability by customers (Crisosto et al., 2003). In processed cherry products, the levels of sugars in fruits also contribute to final product quality. For example the major sugars in sweet cherries, glucose and fructose (which are fermentable sugars) are fermented during wine production to form the alcohol. Therefore the initial level of sugars in fruits can influence the final level of alcohol and sweetness of the wine (Sun, Jiang, \& Zhao, 2012). Therefore harvesting sweet cherries at the correct maturity stage with the high level of sugars is very important to satisfy the consumers of fresh cherries but also for the processing of the fresh fruits.

Total sugar content is often measured by refractometry using a portable digital refractometer (Díaz-Mula, Serrano, \& Valero, 2012). Although this is a convenient and rapid method to estimate sugar levels in cherries, it measures all soluble solids in solution, including acids, amino acids, etc. The content of individual sugars in sweet cherries is usually determined using high-performance liquid chromatography (HPLC) equipped with $\mathrm{NH}_{2}$ or $\mathrm{Ca}^{2+}$ column and a refractive index detector, where a standard curve of pure sugars (glucose, 
fructose, sucrose and sorbitol) is used for quantification. Chromatography columns have been used for sugar analysis in sweet cherries including cross-linked sulfonated polystyrene / divinylbenzene column, or amino column connected with $\mathrm{C}_{18}$ solid-phase-extraction cartridge. Solvents used for the elution system consist of $0.1 \%$ phosphoric acid, $85 \%$ acetonitrile, deionised water, or $0.045 \mathrm{~N} \mathrm{H}_{2} \mathrm{SO}_{4}$ with $6 \%$ acetonitrile (v/v) (Kelebek \& Selli, 2011; Serrano, Guillén, et al., 2005; Usenik et al., 2008).

\subsubsection{Organic acids}

Organic acids are also an important component of the quality of sweet cherries, as they are responsible for the tart or sour taste which contributes to the overall cherry fruit flavour and may influence the quality of processed sweet cherries (Girard \& Kopp, 1998; McLellan \& Padilla-Zakour, 2004). Many organic acids including amino acids, are found in sweet cherries but malic acid is the major organic acid present (Serrano, Guillén, et al., 2005). The content of malic acid differs among different cultivars and ranges from $0.3-0.8 \mathrm{~g} / 100 \mathrm{~g}$ fresh weight (Usenik et al., 2008; McLellan \& Padilla-Zakour, 2004). Similar to the development of sugars during growth, the levels of malic acid in sweet cherries is low during the early stage of growth but increases over the final development stages (Serrano, Guillén, et al., 2005). The total levels and the balance of acids and sugars significantly affect the taste of fruit and consequently influence the acceptance of customers (Crisosto et al., 2003). In addition, the levels of acids in fruit may affect the process operation and quality of processed products. For example, the levels of acids in cherry fruits were found to affect fermentation time and acidity level in the final cherry wine products (Sun et al., 2012).

The TA content in sweet cherries is measured by titration with $0.1 \mathrm{M} \mathrm{NaOH}$ to $\mathrm{pH} 8.1$ (Díaz-Mula et al., 2012; Serradilla et al., 2012). However the content of individual acids such as malic acid, citric acid, succinic acid, ascorbic acid, shikimic acid and fumaric acid are 
usually determined by HPLC and using an absorbance detector at $210 \mathrm{~nm}$. Similar to the analysis of sugars, specific HPLC columns are used for determination of individual acids comprise of cross-linked sulfonated polystyrene / divinylbenzene column, and $\mathrm{C}_{18}$ column (Kelebek \& Selli, 2011; Serrano, Guillén, et al., 2005; Usenik et al., 2008). Quantification of individual acids are done by referring to standard curves of each corresponding acid.

\subsection{Non-nutrient components}

Sweet cherries contain very high levels of anthocyanins and various phenolic compounds, which contribute to the total antioxidant activity and the proported health benefits of sweet cherries (Tomás-Barberán \& Andrés-Lacueva, 2012). However, the levels of anthocyanins and phenolic compounds vary depend on the cultivar, cultivation methods, ripening stages, harvest time and storage conditions (Girard \& Kopp 1998; Serrano, Guillén, et al., 2005; Usenik et al., 2008; Serrano et al., 2009; Serradilla et al., 2012; Ballistreri et al., 2013; Cao et al., 2015). For example, cultivars such as 'Burlat', 'Lala Star' and 'Vesseaux' have been found to contain much higher levels of phenolic compounds than those in other cultivars such as 'Early Van' and 'Fercer' (Usenik et al., 2008). Indeed, production methods such as irrigation, plant density and nutrient management are well-known factors

affecting anthocyanin content of fruits and vegetables. During the final stages of ripening, total antioxidant activity has been shown to be highly correlated to total phenolic and anthocyanin concentrations in 'Marvin-Niram' cherry fruit (Serrano, Guillén, et al., 2005). Phenolic compounds within the fruit have been shown to generally decrease with storage at $1-2^{\circ} \mathrm{C}$ but increase with higher storage temperatures $\left(15 \pm 5^{\circ} \mathrm{C}\right)$ (Gonçalves et al., 2004), however anthocyanin levels increased at both storage temperatures (Gonçalves et al., 2007). The diversity and levels of individual phenolic and anthocyanin compounds in various sweet cherry cultivars are presented in Table 2 . 


\subsubsection{Anthocyanins}

Anthocyanins are responsible for the red colour in cherry fruit, which is the most important indicator of maturity and quality for both fresh and processed cherries (Gao \& Mazza, 1995). Five anthocyanins have been found in sweet cherries; cyanidin 3-glucoside, cyanidin 3-rutinoside, peonidin 3-glucoside, pelargonidin 3-rutinoside and peonidin 3rutinoside (Kelebek \& Selli, 2011; Usenik et al., 2008). Cyanidin 3-rutinoside is the dominant anthocyanin in sweet cherry fruit and accounts for approximately $90 \%$ of the total anthocyanin content. This is followed in decreasing concentration by cyanidin 3-glucoside, pelargonidin-3-rutinoside, peonidin 3-rutinoside and peonidin 3-glucoside (Kelebek \& Selli, 2011; Usenik et al., 2008). However it should be noted that the composition of the individual anthocyanins depends on the cherry cultivar as described in Table 1. In fresh cherries, especially the dark sweet cherries, the development of red colour is used as an index to determine the maturity and to predict processing grades. The darker the fruit colour, the higher content of anthocyanins in the fruit (Gao \& Mazza, 1995). In vitro and in vivo studies have linked anthocyanins with health promoting effects such as prevention of cancers and cardiovascular diseases (He \& Giusti, 2010). Anthocyanins have been found to have anticancer activity against multiple cancer cell types in vitro and tumour types in vivo (Wang \& Stoner, 2008).

Total anthocyanins are often estimated by the pH-differential method (Giusti and Worlstad, 2001). -Individual anthocyanins in sweet cherries are usually determined using HPLC coupled with a detector monitored at 520 or $530 \mathrm{~nm}$. 
Different columns and solvents have been used for each HPLC system (Gao \& Mazza, 1995; Kim et al., 2005; Usenik et al., 2008; Serrano et al., 2009, González-Gómez et al., 2010; Kelebek \& Selli, 2011; Serradilla et al., 2013; Hayaloglu \& Demir, 2016). A C 18 with polar end-capping column with a gradient mobile phase $(100 \mathrm{~mL} / \mathrm{L}$ acetic acid in water (solvent A), and acetonitrile (solvent B), or water: formic acid (95:5, v/v, solvent A) and acetonitrile: solvent A (60:40, v/v, solvent B) was used for quantification of anthocyanins in sweet cherries (Kelebek \& Selli, 2011). A gradient mobile phase of water:methanol (95:5, v/v, solvent A; 88:12, v/v, solvent B; 20:80, v/v, solvent C) and 100\% methanol (solvent D) was also successfully used to identify individual anthocyanins (Serrano et al., 2009).

\subsubsection{Phenolic acids and flavonoids}

In addition to anthocyanins, other phenolic compounds such as phenolic acids and flavonoids are also found in sweet cherries (Table 1). Phenolic acids that have been identified in sweet cherries include neo-chlorogenic acid, chlorogenic acid, p-coumaroyl quinic acid (Gao \& Mazza, 1995; Kelebek \& Selli, 2011; Mozetic, Trebse, \& Hribar, 2002). -These phenolic acids have been reported to be associated with colour, sensory and nutritional qualities and are also related to general fruit maturation and prevention of enzymatic browning (Kappel et al., 1996; Serrano et al., 2009; Serradilla et al., 2012; Hayaloglu \& Demir, 2016). Individual phenolic acids can be identified and quantified using HPLC. Columns and detection wavelengths that have been used for such analysis include $\mathrm{C}_{18}$ column and detected by absorbance at $280 \mathrm{~nm}$ (Usenik et al., 2008), or at $320 \mathrm{~nm}$ (GonzálezGómez et al. 2010; Ballistreri et al. 2013).

Flavonoids such as catechin, epicatechin, rutin, quercetin, quercetin-3-rutinoside, quercetin derivative, and kaempferol derivative have been identified and quantified in sweet 
cherries (Table 2). Individual flavonoids have also been identified and quantified using HPLC. Similar column types using for quantification of phenolic acids can be used for determining individual flavonoids; however, due to the different absorbance of these compounds, flavonoids are measured at wavelengths of $280 \mathrm{~nm}$ (flavan-3-ols), $320 \mathrm{~nm}$ (hydrocinnamic acids) and $360 \mathrm{~nm}$ (flavonols; Ballistreri et al., 2013; Hayaloglu \& Demir, 2016). LC and GC systems coupled with a mass spectrophotometer have also been reported for the characterisation and quantification of phenolic and volatile compounds in sweet cherry (González-Gómez et al., 2010; Serradilla et al., 2012; Ballistreri et al., 2013; Usenik et al., 2015; Hayaloglu \& Demir, 2016). The link between phenolic acids and flavonoids with health benefits such as prevention of cardiovascular diseases, cancers, gout, obesity and diabetes have been outlined in recent reviews (Del Rio et al., 2010; Tomás-Barberán \& Andrés-Lacueva, 2012). A recent study by Bastos et al. (2015) reported that sweet cherry stems contained approximately six times the amount of total phenolic compounds than those in the fleshy fruit and may present opportunities for new valorisation of sweet cherry crop.

\section{Postharvest preservation for fresh markets}

Sweet cherries are mainly consumed as a fresh product with approximately $60 \%$ of total cherry production meeting market specifications and sold into the fresh market (Webster \& Looney, 1996). Harvesting sweet cherries for the fresh market is generally done by hand, as mechanical harvesting generally causes significant damage to the fruit which make the fruit unsuitable for the fresh market (Alonso \& Alique, 2006). Nevertheless, developments in engineering and orchard management are working towards high quality sweet cherry fruit which can be mechanically harvested (Peterson, Whiting, \& Wolford, 2003).

Appearance is an important quality attribute for consumers (Crisosto et al., 2003) where uniformity in fruit colour and size, intense colour, glossy and defect-free skin, and 
having fresh, green, and turgent appearance stems without browning and discolouring are important attributes (Alonso \& Alique, 2006).

Fresh sweet cherries are highly perishable and their shelf-life is relatively short due to their moderate rates of respiratory activity and susceptibility to rapid microbiological decay during storage (Alonso \& Alique, 2006). Therefore, storage temperature and humidity management are critical factors for limiting water loss and dehydration of the fruit and stem, as well as the changes of other physicochemical characteristics.

Controlling storage temperature is the main postharvest technique used to maintain fruit quality during storage. The recommended storage and transport temperature for cherries is $0^{\circ} \mathrm{C}$. However, the recommended temperature for harvesting and handling is between 10 and $20^{\circ} \mathrm{C}$ as within this temperature range the incidence of impact bruising damage is lower (Crisosto, Garner, Doyle, \& Day, 1993). The elimination of the field heat from the fruit in the orchard is typically done by using hydrocooling or forced-air cooling and should be conducted as soon as possible to bring the temperature of the fruits down to $0^{\circ} \mathrm{C}$ for maximum quality and shelf-life (Alonso \& Alique, 2006). However, Bernalte, Sabio, Hernandez, \& Gervasini, (2003) showed that holding 'Van' sweet cherries at $22^{\circ} \mathrm{C}$ for up to $15 \mathrm{~h}$ before transferring to cool storage at $4^{\circ} \mathrm{C}$ did not negatively impact the quality of the fruit after storage.

In addition to cool storage temperatures, relative humidity in the storage environment is another important factor which influences the quality and shelf-life during storage (Wani, Singh, Gul, Wani, \& Langowski, 2014). Relative humidity has been found to relate to the water loss of fruits and stems where the stored fruit in low RH causes increased water loss from the fruit and stem and results in softening of the fruit and stem browning (Golding et al., 2015). The optimum relative humidity for the storage of sweet cherries is between 90 and $95 \%$, where this range of $\mathrm{RH}$ is good at maintaining the green colour of the stem, when the 
storage temperature is at its optimum (Alonso \& Alique, 2006).

Sweet cherry is a non-climacteric fruit with a very low ethylene production during the ripening (Gong, Fan, \& Mattheis, 2002; Li, Andrews, \& Patterson, 1994). Ethylene is a hormone promoting fruit ripening and can influence postharvest life of both climacteric and non-climacteric fruits by influencing their quality attributes and the development of physiological disorders and postharvest diseases (Kader, 1985). Exogenous ethylene has been shown to have no effect on respiration rate and firmness loss during fruit ripening ( $\mathrm{Li}$ et al., 1994), but Gong et al. (2002) showed that exogenous ethylene accelerated the development of stem browning in sweet cherry cultivars, even though 1-MCP had been applied.

Indeed cherry stems are an important component of the acceptability of fresh cherries (Dever et al., 1996). Although cherry stems are not consumed, consumers use the stem as an indicator of freshness (Kappel et al., 1996). However cherry stems have a much thinner epidermis and cuticle layer than the fruit, are very susceptible to water and carbon dioxide losses. Their resistance to water vapour transfer are much lower and can lose water up to eight-times faster than from the fruits (Linke, Herppich, \& Geyer, 2010).

Sweet cherries generally have a short harvest period and marketing window, however with increasing global production and trade in sweet cherry fruit, there is a need to maintain and improve cherry fruit quality during longer storage and marketing times. Finding the most appropriate condition to maintain cherry quality for the fresh markets, particularly on distant export markets is a challenge. In addition to maintaining the cold chain, other postharvest approaches are used and are being investigated. There are generally four categories of postharvest treatments / management to improve storage life; (1) controlled atmosphere (CA) and modified atmosphere packaging (MAP), (2) edible coatings, (3) irradiation, and (4) alternate postharvest decay management. However, these approaches are often used in combination with the cool chain to maximise shelf-life and quality. 


\subsection{Controlled atmosphere (CA) and modified atmosphere packaging (MAP)}

Depending on the cherry cultivar, the storage life of sweet cherries in conventional cold storage in air is 2-4 weeks (Serrano et. al., 2009). However an extension in the storage life of cherries at low temperature is possible when used in combination with controlled atmosphere (CA) or modified atmosphere packaging (MAP), where lower levels of oxygen $\left(\mathrm{O}_{2}\right)$ and higher levels of carbon dioxide $\left(\mathrm{CO}_{2}\right)$ in the storage atmospheres have been shown to improve the storage life of cherries (Goliáš, Němcová, Čaněk, \& Kolenčíková, 2007). Apart from the primary effects of low $\mathrm{O}_{2}$ and high $\mathrm{CO}_{2}$ suppressing cherry fruit respiration rate (Kupferman \& Sanderson, 2001), changes in the levels of $\mathrm{O}_{2}$ and $\mathrm{CO}_{2}$ can also affect other quality parameters such as pigment metabolism, phenolic metabolism and volatile compound metabolism (Goliáš et al., 2007). However the levels of $\mathrm{CO}_{2}$ and $\mathrm{O}_{2}$ need to be carefully maintained as excess $\mathrm{CO}_{2}$ or too low $\mathrm{O}_{2}$ can cause irreversible fruit injury and induce off-flavours and therefore shorten their storage life. Under regular low $\mathrm{O}_{2}$ and / or high $\mathrm{CO}_{2}$, many positive effects of atmospheric-controlled storage of sweet cherries have been reported, including maintaining TA content, and retarding the decline in SSC, retention of firmness, stem colour and brightness, and the reduction of surface pitting and microbial decay (Wang \& Vestrheim, 2002; Serradilla et al., 2012).

At $0-5^{\circ} \mathrm{C}$ storage, sweet cherries have been shown to tolerate very low oxygen levels $\left(0.02 \% \mathrm{O}_{2}\right.$ for $21-25$ days $)$ and can be stored for several weeks in $0.5 \%-1 \% \mathrm{O}_{2}$ or $20 \%-$ $40 \% \mathrm{CO}_{2}$ (Dangyang \& Kader, 1992; Golding et al., 2012). Studies of various CA conditions have been conducted and the use of $10-30 \% \mathrm{CO}_{2}$ and $5-20 \%$ of $\mathrm{O}_{2}$ were reported to be effective in maintaining cherry fruit firmness, vitamin $\mathrm{C}$ and TA levels without the development of off-flavour (Wang \& Vestreim, 2002; Tian, Jiang, Xu, \& Wang, 2004). However there is a discrepancy on the critical level of $\mathrm{CO}_{2}$, as some studies reported sweet 
cherries developed off-flavour when stored in higher than $10 \% \mathrm{CO}_{2}$ and up to $5 \% \mathrm{O}_{2} \mathrm{CA}$ conditions (Goliáš et al., 2007).

Modified atmosphere packaging (MAP) has been extensively studied and is widely commercially used to extend the storage life of cherries (Meheriuk et al., 1995). The benefits of MAP on sweet cherries have been recently reviewed (Wani et al., 2014). These benefits of MAP are the same as CA where low $\mathrm{O}_{2}$ and high $\mathrm{CO}_{2}$ could be used to reduce respiration rates, chemical oxidation rate, and growth of aerobic microorganisms, which consequently increases the storage life of the fruit (Meheriuk et al., 1995). MAP has also been shown to slow the loss of SSC, fruit softening and reduce weight loss in the fruit during storage (Khorshidi, Davarynejad, Tehranifar, \& Fallahi, 2011). Active $\mathrm{O}_{2}$-enriched MAP has also been reported to effectively delay the respiration peak of cherry fruits, retarding ethylene production, and maintaining firmness and soluble protein and sugar contents in the fruits (Wang et al. 2014). The combined use of eugenol, thymol, and menthol essential oils in MAP have been found to enhance the effects of MAP alone, in terms of delaying stem browning, retarding TA loss, and reducing the proliferation of moulds, yeasts, and aerobic mesophilic bacteria during the storage of sweet cherry (Serrano, Martínez-Romero, Castillo, Guillén, \& Valero 2005). MAP with eucalyptol essential oil was effective in inhibiting the growth of microorganisms; however eucalyptol essential oil induced oxidation process and accelerated the rates of stem browning and TA loss (Serrano, Martínez-Romero, et al. 2005).

\subsection{Edible coatings}

Edible coatings have been used to extend the shelf life of fruits and vegetables by acting as a semipermeable film, thus creating a modified atmosphere around the horticultural produce to minimise water loss and slow product respiration rate (Park, 1999). Edible coatings also have been used for the maintenance of cherry fruit quality during storage and 
have been shown to improve their appearance, shelf life and quality (Aday \& Caner, 2010; Díaz-Mula et al., 2012). Several types of coatings such as alginate, gelatine, carboxymethylcellulose, chitosan, whey protein isolate, shellac, calcium chlorides, almond gum, gum arabic, Aloe vera gel, and $\beta$-aminobutyric acid have been reported as edible coatings for cherries (Rojas-Argudo, Pérez-Gago, \& del Río, 2005; Martínez-Romero, et al, 2006; Mahfoudhi \& Hamdi, 2015).

Coated cherries have been reported to have longer shelf life and improved quality parameters such as firmness, weight loss, TA, SSC, ascorbic acid content, and external colour in comparison with uncoated fruit (Aday \& Caner, 2010; Díaz-Mula et al., 2012). However it should be noted that different edible coatings have different properties, thus they have different effects on shelf life of sweet cherries. For instance, a shellac coating was found to be more effective in reducing the respiration rate and maintaining the quality parameters of cherries than chitosan and whey protein isolate coatings (Aday \& Caner, 2010). Coating agents with higher degree of hydrophobicity were found to be more effective in maintaining fruit weight and firmness, as well as delaying deterioration. (Rojas-Argudo et al., 2005).

\subsection{Irradiation}

Irradiation was first applied onto sweet cherries for quarantine purposes where a dose of less than $1 \mathrm{kGy}$ gamma irradiation was effective for fruit fly and codling moth disinfestation (Jessup, 1990). However irradiation treatment has also been shown to help prolong the shelf-life of sweet cherries by inhibiting the growth of fungi and delaying senescence (Wilkinson \& Gould, 1998). The effects of irradiation on the other quality attributes in cherry have been reported (Jessup et al., 1990; Neven \& Drake, 2000). In general, irradiation at a high dose (1 kGy) does not affect firmness, SSC, external damage, and fruit weight but has been shown to induce stem discolouration (Jessup, 1990). Irradiation 
sensitivity varies between different cultivars (Jessup, 1990; Neven \& Drake, 2000). A review on the effects of irradiation treatments on phytochemicals and antioxidants in a range of produce concluded that irradiation generally did affect the levels of antioxidants/phytochemicals differently in different produce (Alothman, Bhat \& Karim, 2009). Irradiation could either enhance or lower the level of plant phytochemicals, depending a number of factors such as, radiation dose, exposure time, storage temperature, sensitivity of the antioxidant / phytochemical, and plant materials (Alothman et al., 2009).

\subsection{Alternatives to postharvest fungicides}

Postharvest fungal pathogens are one of the major causes of postharvest losses in the fresh market. Fungal pathogens of concern in sweet cherries include Penicillium expansum Link (blue mould), Monilinia spp. (brown rot), Alternaria alternata (Fr.:Fr.) Keissl (Alternaria rot), Rhizopus stolonifera (Erhenb.:Fr.) Vuill (Rhizopus rot), and Botrytis cinerea Pers.:Fr. (grey mould) (Alonso \& Alique, 2006). These pathogens can be controlled with the use of synthetic postharvest fungicides, but there is a growing consumer and regulatory resistance to their continued use. Biological control (or biocontrol) has been extensively studied in the last 30 years to maintain fruit quality where use microbial antagonists (either existing microorganisms on the produce itself, or from other sources) to control postharvest decay (Sharma, Singh, \& Singh, 2009; Lima, Sanzani, De Curtis, \& Ippolito, 2015). Many studies showed promising results of using antagonists to control pathogenic decay in a range of horticultural crops (Sharma et al., 2009; Jamalizadeh, Etebarian, Aminian, \& Alizadeh, 2011; Lima et al., 2015). Microbial antagonists work through various modes of actions, including competition, antibiosis, parasitism, induced resistance in the host tissue, and production of volatile metabolites. The details of action mechanisms, traits of desirable microbial antagonists, and the use of microbial antagonists have been reviewed (Sharma et 
al., 2009; Jamalizadeh et al., 2011). To be effective, antagonists need to be introduced onto the surface or the wound sites of the fruits before the arrival of pathogens, so that they can compete for nutrients and niche exclusion.

The use of yeast antagonists to control diseases and decay from these pathogens has been examined before and after harvest on sweet cherries, where several antagonists were reported to be effective (Tian, Qin, \& Xu, 2004; Oro, Feliziani, Ciani, Romanazzi, \& Comitini, 2014). Enhancement of the efficacies of yeast antagonists can be achieved when used in combination with cold storage and/or other postharvest treatments, such as antimicrobial compounds (sodium bicarbonate, potassium sorbate, salicylic acid, and ammonium molybdate) and CA storage (Karabulut, Lurie, \& Droby, 2001; Tian, Jiang, et al., 2004). However CA does not always give positive effects on the survival and persistence of biological control agents where their growth might be suppressed under CA storage (Qin, Tian, \& Xu, 2004). Furthermore, research has also suggested that induction of defence response against pathogen-induced oxidative stress may be the main mechanism of the yeast antagonists (Xu \& Tian, 2008).

\section{Processing of sweet cherries}

There is an established tart cherry processing industry which produces a range of important food products (McLellan \& Padilla-Zakour, 2004). Even for sweet cherry, approximately $60 \%$ of all sweet cherries going to the fresh market (McCune et al., 2011), the remaining $40 \%$ of cherry production are either processed or discarded. Thus there is a large supply of sweet cherries which can be processed into cherry products such as frozen, canned, brined, juice, wine, dried forms, jams, and jellies (McLellan \& Padilla-Zakour, 2004).

The reasons why tart cherry is often used in the processing industry is due to a combination of technical and economic aspects. From the technical point of view, tart cherry 
offers some advantages over sweet cherry especially in the beverages industry due to its physiochemical properties. In comparison to sweet cherry, tart cherry fruit contains lower amounts of hydrocolloids (pectin gels ionically linked by $\mathrm{Ca}^{2+}$ bridges) in the cell wall. By containing lower amount of hydrocolloids, tart cherries gives higher juice

yield and lower juice retention in the pulp even without enzymatic treatment. Furthermore, tart cherry fruits contain higher amounts of volatile aroma compounds (e.g. benzaldehyde, eugenol, and linalool) than sweet cherry fruits (Sun et al., 2012; Wen et al., 2014). These volatile aromatics are of importance to the fruity flavour and flowery aroma in cherry beverages and fermented cherry products (Śliwińska, Wiśniewska, Dymersji, Wardencki, \& Namieśnik, 2015). In an economic perspective, sweet cherry is considered a high-valued fruit where growers receive the highest return on investment by entering the fresh market, not by supplying to the food processing industry (Sredojević et al., 2011). Thus the majority of sweet cherry production is aimed at the fresh market. However, alternative valorisation of sweet cherry has been reported (Bastos et al., 2015).

\section{Cherry products}

Frozen cherries. Preserving cherries by conventional freezing technique is generally performed at $-18^{\circ} \mathrm{C}$ or below (McLellan \& Padilla-Zakour, 2004). Since freezing causes a reduction in fruit turgidity and firmness, individually quick freezing (IQF) technique is a better approach. IQF is a rapid freezing process suitable for food with small size and uniform shape, such as cherries (Reid \& Barrett, 2005). The food can be frozen individually and rapidly in a low-temperature, high air velocity blast freezer or in a cryogenic freezer which provides a more uniform freezing rate over the whole product, resuting in less freezing damage to the products comparing to slow freezing methods (Reid \& Barrett, 2005). Cherries 
can successfully be treated to prevent browning and flavour loss by IQF technique at $-35^{\circ} \mathrm{C}$ without the addition of sugar. Frozen cherries have been found to contain higher levels of anthocyanins, carotenoids and vitamin $\mathrm{C}$ compared to those processed by wet-heat and freeze-drying technique (Leong \& Oey, 2012).

Canned and jar cherries. For canning sweet cherries, fruits are soaked and filled into cans or jars together with syrup before entering exhausting tunnel and processing at high temperature (McLellan \& Padilla-Zakour, 2004). Application of heat at pasteurisation and sterilisation temperatures can affect the firmness of the final products, thus the temperature and duration are very important factors determining the quality of canned sweet cherries (McLellan \& Padilla-Zakour, 2004). During thermal processing cherry fruit anthocyanins and phenolic compounds leach from the fruit into the syrup and losses of these bioactive compounds during storage have been reported (Chaovanalikit \& Wrolstad, 2004).

Brined cherries. Mature whole cherries are used in brining which are packed in a solution containing $1-1.5 \%$ sulphur dioxide, which is sufficient for this preservation purpose. When preserving in brine, the cherry fruit may soften due to cracks developing in the skin of the fruits. In addition, brined cherry fruit can often have solution pockets in which there are gaseous pockets formed in the fruit resulting in the undesirable breakdown of the fruit which can completely degrade the fruit (McLellan \& Padilla-Zakour, 2004). Another quality issue after brining is that only a small quantity of anthocyanins and phenolic compounds remained in the preserved cherry fruit (Chaovanalikit \& Wrolstad, 2004).

Juice. Although most of cherry juice is made from tart cherries, sweet cherries are also used to make high quality cherry juice especially the cultivars with high anthocyanin contents 
(Schüller et al., 2015). The juice can be made by two extraction processes: hot extraction $\left(70^{\circ} \mathrm{C}\right)$ and cold extraction methods. These two processes yield reasonable quality products. However, turbidity, haze, and sediments occur in the juice and affect the quality of the final products, thus clarification and filtration are needed at the final stage of the juice manufacturing process (Horváth-Kerkai, 2006). Novel processing techniques, such as pulsed electric field (PEF; $30 \mathrm{kV}$ electric filed strengths, $3 \mu$ s pulse duration, 500 pps repetition rate, and $131 \mu$ s treatment time) and high hydrostatic pressure (HHP; $350 \mathrm{MPa}$ for $5 \mathrm{~min}$ at $40^{\circ} \mathrm{C}$ ) treatment, have been found to be effective in inactivation of vegetative cells and spores of many pathogens in tart cherry juice (such as Penicillum expansum, Escherichia coli O157:H7, Staphylococcus aureus, Pseudomonas syringae subs. syringae, Botrytis cinerea, Erwinia caratowora, and Listeria monocytogenes (Alpas \& Bozoğlu, 2003; Altuntas, Evrendilek, Sangun, \& Zhang, 2010). The inactivation of microorganisms with PEF and HHP are significant benefits in cherry juice production.

Wine. Sweet and tart cherries are used in the production of cherry wine which have special characteristics and distinct flavours (Niu et al., 2012; Sun et al., 2012). Taste and mouthfeel are the major determinants of consumer preference and acceptance for wines. Niu et al. (2012) studied some taste-active compounds in cherry wines such as lactic acid, succinic acid, proline, asparagine, glucose, fructose, and tannic acid and found that these compounds had a significant contribution to the characteristic taste or mouthfeel. Thus cherry wine quality can be improved by modifying fermentation parameters or adjusting these typical taste-active compounds after alcoholic fermentation.

Distilled cherry products. Cherry liqueur and distilled spirits (such as Kirschwasser, cseresznyepálinka, brandy) are produced in many regions in Europe (Śliwińska, et. al, 2015). 
Cherry spirits are manufactured by fermentation and distillation from cherry must (freshly pressed cherry juice containing the skins, seeds, and stems), resulting in spirits of at least 37.5 $\%$ up to $70 \%$ v/v ethanol (Śliwińska, et. al, 2015). During the production of the cherry juice, the cherry pits or stones can be crushed. The cherry pits contain a compound called amygdalin which when subject to enzymatic degradation produces benzaldehyde (Christoph \& Bauer-Christoph, 2007). Benzaldehyde has a characteristic pleasant almond-like odour and is a desirable flavour attribute of cherry wine (Christoph \& Bauer-Christoph, 2007). Studies on distillation process configuration, effects of pit / stone content, cultivar and distillation steps, extraction of anthocyanin pigments, as well as volatile compounds and phenolic contents in cherry brandy and liqueur have been reported (Schehl, Lachenmeier, Senn, \& Heinisch, 2005; Rødtjer, Skibsted, \& Anderson, 2006).

Dried cherries. Sweet cherries can also be dehydrated to produce dried cherries and other cherry products. The method applied for producing dried cherries is similar to that used in canning; however the fruits used in the drying process must be fully ripe cherries with high sugar levels (McLellan \& Padilla-Zakour, 2004). Although freeze-drying has been shown to maintain excellent colour and pigment retention, air-drying with blanching pretreatment was reported to be the best method in obtaining high phenolic content and antiradical power of the final product (Franceschinis, Sette, Schebor, \& Salvatori, 2015).

Colourants and dyes. The use of anthocyanins as natural colourants are of considerable interest as they are attractive to the consumers' perception both in terms of organoleptic properties and safety (He \& Giusti, 2010). Anthocyanins in tart cherries have been isolated and stabilised (Chandra, Nair, \& Iezzoni, 1993) and identified and quantified by HPLC and HPLC-MS (Chandra, Rana, \& Li, 2001). Anthocyanins from dark, tart cherries can be used 
as colorants for the production of maraschino-type cherries (McLellan \& Cash 1979).

In addition to the traditional processing processes for the abovementioned sweet cherry products, novel techniques such as high hydrostatic pressure (HHP), pulsed electric field (PEF), and cryoconcentration, have also been investigated to enhance the organoleptic, nutritional, and microbiological quality of processed cherries (Aider \& de Halleux, 2008; Evrendilek et al., 2012; Queirós et al., 2014).

\section{Trends for future use of sweet cherries}

In addition to the traditional uses of sweet cherry fruit as a fresh product and even in a processed form (e.g. juice or frozen), there has been a growing interest in the recovery of bioactive compounds for the development of functional foods or health therapies (Serra et al., 2010).

A proposed development of processed products from lower quality sweet cherries is shown in Figure 1. Besides the development of new processed products from the sweet cherries, bioactive-based products including crude extracts, mixture extracts, or purified extracts with high purity of individual compounds should be developed based on new and emerging processing technologies. Several attempts have been made to produce cherry products, which are rich in bioactive components for further utilisation in the food or pharmaceutical industries. Serra et al. (2010) employed supercritical carbon dioxide extraction coupled with enhanced solvent extraction to enrich the bioactive components in cherry extracts and found that the refined extract contained high antioxidant activity and was effective in inhibiting the growth of human colon cancer cells. Using highly pure $\mathrm{CO}_{2}$ and $96 \%$ ethanol for further extraction, the concentrated extract was found to have 16-fold higher level of inhibition of cancer cell growth (Serra et al., 2011).

Kim et al. (2005) developed a method to produce a phenolic rich extract and 
anthocyanins from sweet cherries through numerous steps including extraction of phenolic compounds from cherries using homogenization and sonication with methanol as solvent. This phenolic extract was further used for fractionation to obtain pure anthocyanins using C18 Sep-Pak cartridges with $0.1 \%$ (v/v) $\mathrm{HCl}$ as the elution solvent. This method was scaled up to produce extract with high content of anthocyanins, however the anthocyanin recovery was low and the undesirable use of methanol solvent was used in the process. It is important to note at that due to the health and economic concerns, future extraction and processing methods must be economical, safe, sustainable and environmentally friendly. Grigoras, Destandau, Zubrzycki, \& Elfakir (2012) developed a method to produce an anthocyanin rich extract from cherries by applying microwave with 4 heating cycles of $45 \mathrm{~s}$ each at a power of $1000 \mathrm{~W}$ for extracting anthocyanins from cherries without using solvents. They then used semi-preparative liquid chromatography which used a safe and biodegradable isocratic mobile phase consisting in a water/ethanol/formic acid mixture circulating in a 'closed loop' system for isolating anthocyanins. From a $200 \mathrm{mg}$ of crude sweet cherry extract, $1 \mathrm{mg}$ of cyanidin3-O-glucoside and $2 \mathrm{mg}$ of cyanidin-3-O-rutinoside could be recovered with purity of over 97\% (Grigoras et al., 2012).

Although several methods have been developed to efficiently extract sweet cherry phenolics, these methods can be improved to enhance productivity by optimising the extraction conditions such as pressure, time, temperature, ratio of solvent to sample, particle size of sample and/or the types of solvent. In addition, novel methods such as subcritical water extraction and ultrahigh pressure should be explored for extracting the bioactive components from the sweet cherries. Optimisation of concentration/drying conditions via different techniques, such as membrane filtration, cryoconcentration, vacuum drying, freeze drying and spray drying for sweet cherry crude extracts is also worthwhile as these bioactive components are known to be heat-sensitive. Although a specific method for 
fractionation/purification of bioactive components from sweet cherries has not been fully developed, there is a great potential for utilisation of the current technology to achieve such a goal. Several methods such as column chromatography, resins, solid-phase extraction can be applied to enrich bioactive components in the cherry extracts as they have been used widely for isolation of bioactive compounds from other sources (Scoma, Pintucci, Bertin, Carlozzi, \& Fava, 2012).

There is also significant potential for the utilisation of phenolics from cherry stems. As previously mentioned, sweet cherry stems have been shown to contain approximately six times the amounts of total phenolic compounds higher than those in the fleshy fruits (Bastos et al., 2015). Stems are significant waste product in the cherry handling and packing process and there are opportunities for the valorisation of sweet cherry stems.

Many of the individual bioactive components in the sweet cherries such as cyanidin 3glucoside, -catechins, kaempferol 3-rutinoside, and quercetic 3-rutinoside have been linked with various health benefits (He \& Giusti, 2010; Del Rio et al., 2010; Tomás-Barberán \& Andrés-Lacueva, 2012). Most of the current therapies, especially for treatment of cancer have been derived from natural resources (Newman \& Cragg, 2012), therefore further purification of individual compounds which are rich in the sweet cherries should be encouraged to prepare materials for utilisation in the health and pharmaceutical industries. Several methods such as column chromatography and molecularly imprinted polymers (MIPs) have been developed to successfully purify bioactive components from plants (Cheong, Yang, \& Ali, 2013). Future study is needed to develop method for purification of active natural compounds from the sweet cherries. However it is essential that any commercial process is economical, sustainable, and environmentally friendly. 


\section{Conclusions}

Sweet cherries contain high levels of nutrient and non-nutrient compounds associated with human health benefits. The global market value, production and harvested area of sweet cherries have rapidly increased over the last 15 years and continues to grow, signifying their growing importance in the food and horticultural industries. Although major progress on preand postharvest treatments to improve fruit quality and market access have been made, more research is still needed to achieve high quality fruit that meet the expectations of the consumers, as well as improved return-on-investment for growers. Apart from improving the quality and market access of sweet cherries in the fresh market, valorisation of market-second cherries is an important component to add-value to this currently under-utilised resource and more research and development is needed. In addition to processed products, such as dried and frozen cherries and cherry juice, research and development on extraction/fractionation/purification of bioactive components from second-grade cherries fruits and stems is worth pursuing as they are known to be a rich source many healthpromoting compounds.

\section{Acknowledgements}

This study was supported by NSW Department of Primary Industries and the Australian Research Council Training Centre for Food and Beverage Supply Chain Optimisation, IC140100032. NSW Department of Primary Industries is a partner organisation in this Training Centre.

\section{References}

Aday, M. S., \& Caner, C. (2010). Understanding the effects of various edible coatings on the storability of fresh cherry. Packaging Technology and Science, 23, 441-456. 
Aider, M., \& de Halleux, D. (2008). Production of concentrated cherry and apricot juices by cryoconcentration technology. LWT - Food Science and Technology, 41, 1768-1775.

Alonso, J., \& Alique, R. (2006). Sweet Cherries. In Y. H. Hui, J. Barta, M. P. Cano, T. W. Gusek, J. S. Sidhu, \& N. K. Sinha (Eds.), Handbook of Fruits and Fruit Processing (pp. 359-367). Oxford: Blackwell Publishing.

Alothman, M., Bhat, R., \& Karim, A.A. (2009). Effects of radiation processing on phytochemicals and antioxidants in plant produce. Trends in Food Science and Technology, 20, 201-212.

Alpas, H., \& Bozoglu, F. (2003). Efficiency of high pressure treatment for destruction of Listeria monocytogenes in fruit juices. FEMS Immunology \& Medical Microbiology, $35,269-273$.

Altuntas, J., Evrendilek, G. A., Sangun, M. K., \& Zhang, H. Q. (2010). Effects of pulsed electric field processing on the quality and microbial inactivation of sour cherry juice. International Journal of Food Science \& Technology, 45, 899-905.

Ballistreri, G., Continella, A., Gentile, A., Amenta, M., Fabroni, S., \& Rapisarda, P. (2013). Fruit quality and bioactive compounds relevant to human health of sweet cherry (Prunus avium L.) cultivars grown in Italy. Food Chemistry, 140, 630-638.

Bastos, C., Barros, L., Dueñas, M., Calhelha, R. C., Queiroz, M. J. R. P., Santos-Buelga, C., \& Ferreira, I. C. F. R. (2015). Chemical characterisation and bioactive properties of Prunus avium L.: The widely studied fruits and the unexplored stems. Food Chemistry, 173, 1045-1053.

Bernalte, M. J., Sabio, E., Hernandez, M. T., \& Gervasini, C. (2003). Influence of storage delay on quality of 'Van' sweet cherry. Postharvest Biology and Technology, 28, 303312. 
Cao, J., Jiang, Q., Lin, J., Li, X., Sun, C., \& Chen, K. (2015). Physicochemical characterisation of four cherry species (Prunus spp.) grown in China. Food Chemistry, 173, 855-863.

Chandra, A., Nair, M. G., \& Iezzoni, A. F. (1993). Isolation and stabilization of anthocyanins from tart cherries (Prunus cerasus L.). Journal of Agricultural and Food Chemistry, $41,1062-1065$

Chandra, A., Rana, J., \& Li, Y. (2001). Separation, identification, quantification, and method validation of anthocyanins in botanical supplement raw materials by HPLC and HPLC-MS. Journal of Agricultural and Food Chemistry, 49, 3515-3521.

Chaovanalikit, A., \& Wrolstad, R. E. (2004). Total anthocyanins and total phenolics of fresh and processed cherries and their antioxidant properties. Journal of Food Science, 69, FCT67-FCT72.

Cheong, W. J., Yang, S. H., \& Ali, F. (2013). Molecular imprinted polymers for separation science: A review of reviews. Journal of Separation Science, 36, 609-628.

Christoph, N., \& Bauer-Christoph, C. (2007). Flavour of spirit drinks: raw materials, fermentation, distillation, and aging. In R. G. Berger (Ed.), Flavours and Fragrances: Chemistry, Bioprocessing, and Sustainability (pp. 219-239). Berlin: Springer-Verlag.

Crisosto, C. H., Crisosto, G. M., \& Metheney, P. (2003). Consumer acceptance of 'Brooks' and 'Bing' cherries is mainly dependent on fruit SSC and visual skin color. Postharvest Biology and Technology, 28 150-167.

Crisosto, C. H., Garner, D., Doyle, J., \& Day, K. R. (1993). Relationship between fruit respiration, bruising susceptibility, and temperature in sweet cherries. HortScience, $28,132-135$. 
Dangyang, K., \& Kader, A. A. (1992). External and internal factors influence fruit tolerance to low-oxygen atmospheres. Journal of the American Society for Horticultural Science, 117, 913-918.

Del Rio, D., Costa, L. G., Lean, M. E. J., \& Crozier, A. (2010). Polyphenols and health: What compounds are involved? Nutrition, Metabolism and Cardiovascular Diseases, 20, 16.

Dever, M. C., MacDonald, R. A., Cliff, M. A., \& Lane, W. D. (1996). Sensory evaluation of sweet cherry cultivars. HortScience, 31, 150-153.

Díaz-Mula, H. M., Serrano, M., \& Valero, D. (2012) Alginate coatings preserve fruit quality and bioactive compounds during storage of sweet cherry fruit. Food and Bioprocess Technology, 5, 2990-2997.

Esti, M., Cinquanta, L., Sinesio, F., Moneta, E., \& Di Matteo, M. (2002). Physicochemical and sensory fruit characteristics of two sweet cherry cultivars after cool storage. Food Chemistry, 76, 399-405.

Evrendilek, G. A., Baysal, T., Icier, F., Yildiz, H., Demirdoven, A., \& Bozkurt, H. (2012). Processing of fruits and fruit Juices by novel electrotechnologies. Food Engineering Reviews, 4, 68-87.

FAOSTAT. FAO statistic database. Accessed on 1 February 2015, from http://faostat3.fao.org/home/E.

Franceschinis, L., Sette, P., Schebor, C., \& Salvatori, D. (2015). Color and bioactive compounds characteristics on dehydrated sweet cherry products. Food and Bioprocess Technology, 8, 1716-1729.

Gao, L., \& Mazza, G. (1995). Characterization, quantitation, and distribution of anthocyanins and colorless phenolics in sweet cherries. Journal of Agricultural and Food Chemistry, 43, 343-346. 
Girard, B., \& Kopp, T. G. (1998). Physicochemical characteristics of selected sweet cherry cultivars. Journal of Agricultural and Food Chemistry, 46, 471-476.

Golding, J.B., Jessup A., Spohr L., Daniels D., Satyan S., Pristijono P., McGlasson B. \& Jacas J. (2012) Efficacy of a combination quarantine treatment at $3^{\circ} \mathrm{C}$ as a potential disinfestation treatment for Queensland Fruit Fly (Bactrocera tryoni (Froggatt)) in cherry fruit. Acta Horticulturae, 934, 343-346.

Golding, J.B., Spohr, L., Harris, A., Satyan, S., Blades, B., Crampton, K., Bullot, M., Stathopoulos, C., \& McGlasson, W.B. (2015) Effect of postharvest display conditions on cherry stem quality. In Press Acta Horticulturae.

Goliáš, J., Němcová, A., Čaněk, A., \& Kolenčíková, D. (2007). Storage of sweet cherries in low oxygen and high carbon dioxide atmospheres. Horticultural Science, 34, 26-34.

Gonçalves, B., Landbo, A. K., Knudsen, D., Silva, A. P., Moutinho-Pereira, J., Rosa, E., \& Meyer, A. S. (2004). Effect of ripeness and postharvest storage on the phenolic profiles of cherries (Prunus avium L.). Journal of Agricultural and Food Chemistry, $52,523-530$.

Gonçalves, B., Silva, A. P., Moutinho-Pereira, J., Bacelar, E., Rosa, E., \& Meyer, A. S. (2007). Effect of ripeness and postharvest storage on the evolution of colour and anthocyanins in cherries (Prunus avium L.). Food Chemistry, 103, 976-984.

Gong, Y. P., Fan, X. T., \& Mattheis, J. P. (2002). Response of 'Bing' and 'Rainier' sweet cherries to ethylene and 1-methylcyclopropene. Journal of the American Society for Horticultural Science, 127, 831-835.

González-Gómez, D., Lozano, M., Fernández-León, M. F., Bernalte, M. J., Ayuso, M. C., \& Rodríguez, A. B. (2010). Sweet cherry phytochemicals: Identification and characterization by HPLC-DAD/ESI-MS in six sweet-cherry cultivars grown in Valle del Jerte (Spain). Journal of Food Composition and Analysis, 23, 533-539. 
Grigoras, C. G., Destandau, E., Zubrzycki, S., \& Elfakir, C. (2012). Sweet cherries anthocyanins: An environmental friendly extraction and purification method. Separation and Purification Technology, 100, 51-58.

Giusti, M. M., \& Wrolstad, R. E. (2001). Characterization and measurement of anthocyanins by UV-visible spectroscopy. In R. E. Wrolstad, T. E. Acree, H. An, E. A. Decker, M. H. Penner, D. S. Reid, S. J. Schwartz, C. F. Shoemaker, \& P. Sporns (Eds.), Current Protocols in Food Analytical Chemistry (pp F1.2.1-F1.2.13). New York: John Wiley \& Sons.

Hayaloglu, A. A., \& Demir, N. (2015). Physicochemical characteristics, antioxidant activity, organic acid and sugar contents of 12 sweet cherry (Prunus avium L.) cultivars grown in Turkey. Journal of Food Science, 80, C564-C570.

Hayaloglu, A. A., \& Demir, N. (2016). Phenolic compounds, volatiles, and sensory characteristics of twelve sweet cherry (Prunus avium L.) cultivars grown in Turkey. Journal of Food Science, 81, C7-C18.

He, J., \& Giusti, M. M. (2010). Anthocyanins: Natural colorants with health-promoting properties. Annual Review of Food Science and Technology, 1, 163-187.

Horváth-Kerkai, E. (2006). Manufacturing Fruit Beverages. In Y. H. Hui, J, Barta, M. P. Cano, T. W. Gusek, J. S. Sidhu, \& N. K. Sinha (Eds.), Handbook of Fruits and Fruit Processing (pp. 205-215). Iowa: Blackwell Publishing.

Iezzoni, A. F. (2008). Cherries. In J. F. Hancock (Ed.), Temperate Fruit Crop Breeding: Germplasm to Genomics (pp. 151-175). The Netherlands: Springer.

Jamalizadeh, M., Etebarian, H. R., Aminian, H., \& Alizadeh, A. (2011). A review of mechanisms of action of biological control organisms against post-harvest fruit spoilage. EPPO Bulletin, 41, 65-71. 
Jessup, A. J. (1990). Gamma irradiation as a quarantine treatment for sweet cherries against Queensland fruit fly. HortScience, 25, 456-458.

Kader, A.A. (1985). Ethylene-induced senescence and physiological disorders in harvested horticultural crops. HortScience, 20, 54-57.

Kappel, F., Fisher-Fleming, B., \& Hogue, E. (1996). Fruit characteristics and sensory attributes of an ideal sweet cherry. HortScience, 31, 443-446.

Karabulut, O. A., Lurie, S., \& Droby, S. (2001). Evaluation of the use of sodium bicarbonate, potassium sorbate and yeast antagonists for decreasing postharvest decay of sweet cherries. Postharvest Biology and Technology, 23, 233-236.

Kelebek, H., \& Selli, S. (2011). Evaluation of chemical constituents and antioxidant activity of sweet cherry (Prunus avium L.) cultivars. International Journal of Food Science and Technology, 46, 2530-2537.

Khorshidi, S., Davarynejad, G., Tehranifar, A., \& Fallahi, E. (2011). Effect of modified atmosphere packaging on chemical composition, antioxidant activity, anthocyanin, and total phenolic content of cherry fruits. Horticulture, Environment, and Biotechnology, 52, 471-481.

Kim, D.-O., Heo, H. J., Kim, Y. J., Yang, H. S., \& Lee, C. Y. (2005). Sweet and sour cherry phenolics and their protective effects on neuronal cells. Journal of Agricultural and Food Chemistry, 53, 9921-9927.

Kupferman, E., \& Sanderson, P. (2001). Temperature management and modified atmosphere packing to preserve sweet cherry quality. Postharvest Information Network, 1, 1-9. Retrieved from http://postharvest.tfrec.wsu.edu/EMK2001B.pdf.

Leong, S. Y., \& Oey, I. (2012). Effects of processing on anthocyanins, carotenoids and vitamin C in summer fruits and vegetables. Food Chemistry, 133, 1577-1587. 
Li, S., Andrews, P. K., \& Patterson, M. E. (1994). Effects of ethephon on the respiration and ethylene evolution of sweet cherry (Prunus avium L.) fruit at different development stages. Postharvest Biology and Technology,4, 235-243.

Lima, G., Sanzani, S.M., De Curtis, F., \& Ippolito, A. (2015). Biological control of postharvest diseases. In R. B. H. Wills, \& J. B. Golding (Eds.), Advances in Postharvest Fruit and Vegetable Technology (pp. 65-88). Boca Raton: CRC Press.

Linke, M., Herppich, W. B., \& Geyer, M. (2010). Green peduncles may indicate postharvest freshness of sweet cherries. Postharvest Biology and Technology, 58, 135-141.

Looney, N., \& Jackson, D. (2011). Stone Fruits. In D. I. Jackson, N. E. Looney, M. MorleyBunker, and G. F. Thiele (Eds.). Temperate and Subtropical Fruit Production (pp. 161-180). Cambridge: Cambridge University Press.

Mahfoudhi, N., \& Hamdi, S. (2015). Use of almond gum and gum arabic as novel edible coating to delay postharvest ripening and to maintain sweet cherry (Prunus avium) quality during storage. Journal of Food Processing and Preservation. 39, 1499-1508.

Martínez-Romero, D., Alburquerque, N., Valverde, J. M., Guillén, F., Castillo, S., Valero, D., \& Serrano, M. (2006). Postharvest sweet cherry quality and safety maintenance by Aloe vera treatment: A new edible coating. Postharvest Biology and Technology, 39, 93-100.

McCune, L. M., Kubota, C., Stendell-Hollis, N. R., \& Thomson, C. A. (2011). Cherries and health: A review. Critical Reviews in Food Science and Nutrition, 51, 1-12.

McLellan, M. R., \& Cash, J. N. (1979). Application of anthocyanins as colorants for Marascino-Type cherries. Journal of Food Science, 44, 483-487.

McLellan, M. R., \& Padilla-Zakour, O. I. (2004). Sweet cherry and sour cherry processing. In D. M. Barrett, L. P. Somogyi \& H. S. Ramaswamy (Eds.), Processing fruits: Science and Technology (pp. 497-508). Boca Raton: CRC Press. 
Meheriuk, M., Girard, B., Moyls, L., Beveridge, H. J. T., McKenzie, D. L., Harrison, J., Weintraub, S., \& Hocking, R. (1995). Modified atmosphere packaging of 'Lapins' sweet cherry. Food Research International, 28, 239-244.

Mozetic, B., Trebse, P., \& Hribar, J. (2002). Determination and quantitation of anthocyanins and hydroxycinnamic acids in different cultivars of sweet cherries (Prunus avium L.) from Nova Gorica region (Slovenia). Food Technology and Biotechnology, 40, 207212.

Neven, L. G., \& Drake, S. R. (2000). Comparison of alternative postharvest quarantine treatments for sweet cherries. Postharvest Biology and Technology, 20, 107-114.

Newman, D. J., \& Cragg, G. M. (2012). Natural products as sources of new drugs over the 30 years from 1981 to 2010. Journal of Natural Products, 75, 311-335.

Niu, Y., Zhang, X., Xiao, Z., Song, S., Jia, C., Yu, H., Fang, L., \& Xu, C. (2012). Characterization of taste-active compounds of various cherry wines and their correlation with sensory attributes. Journal of Chromatography B, 902, 55-60.

Oro, L., Feliziani, E., Ciani, M., Romanazzi, G., \& Comitini, F. (2014). Biocontrol of postharvest brown rot of sweet cherries by Saccharomyces cerevisiae Disva 599, Metschnikowia pulcherrima Disva 267 and Wickerhamomyces anomalus Disva 2 strains. Postharvest Biology and Technology, 96, 64-68.

Park, H. J. (1999). Development of advanced edible coatings for fruits. Trends in Food Science \& Technology, 10, 254-260.

Peterson, D. L., Whiting, M. D., \& Wolford, S. D. (2003) Fresh-market quality tree fruit harvester. Part I: sweet cherry. Applied Engineering in Agriculture, 19, 539-543.

Qin, G., Tian, S., \& Xu, Y. (2004). Biocontrol of postharvest diseases on sweet cherries by four antagonistic yeasts in different storage conditions. Postharvest Biology and Technology, 31, 51-58. 
Queirós, R. P., Rainho, D., Santos, M. D., Fidalgo, L. G., Delgadillo, I., \& Saraiva, J. A. (2014). High pressure and thermal pasteurization effects on sweet cherry juice microbiological stability and physicochemical properties. High Pressure Research, $35,69-77$.

Reid, D. S., \& Barrett, D. M. (2005). Fruit freezing. In M. D. Barrett, L. Somogyi, \& H. Ramaswamy (Eds.), Processing Fruits: Science and Technology (pp. 161-172). Boca Raton: CRC Press.

Rødtjer, A., Skibsted, L. H., \& Andersen, M. L. (2006). Identification and quantification of phenolics in aromatic bitter and cherry liqueur by HPLC with electrochemical detection. European Food Reseach and Technology, 223, 663-668.

Rojas-Argudo, C., Pérez-Gago, M. B., \& del Río, M. A. (2005). Postharvest quality of coated cherries cv. 'Burlat' as affected by coating composition and solids content. Food Science and Technology International, 11, 417-424.

Schehl, B., Lachenmeier, D., Senn, T., \& Heinisch, J. J. (2005). Effect of the stone content on the quality of plum and cherry spirits produced from mash fermentations with commercial and laboratory yeast strain. Journal of Agriculture and Food Chemistry, $53,8230-8238$.

Schüller, E., Halbwirth, H., Mikulic-Petkovsek, M., Slatnar, A., Veberic, R., Forneck, A., Stich, K., \& Spornberger, A. (2015). High concentrations of anthocyanins in genuine cherry-juice of old local Austrian Prunus avium varieties. Food Chemistry, 173, 935942.

Schuster, M. (2012). Incompatible (S-) genotypes of sweet cherry cultivars (Prunus avium L.). Scientia Horticulturae, 148, 59-73.Scoma, A., Pintucci, C., Bertin, L., Carlozzi, P., \& Fava, F. (2012). Increasing the large scale feasibility of a solid phase extraction 
procedure for the recovery of natural antioxidants from olive mill wastewaters. Chemical Engineering Journal, 198-199, 103-109.

Scoma, A., Pintucci, C., Bertin, L., Carlozzi, P., \& Fava, F. (2012). Increasing the large scale feasibility of a solid phase extraction procedure for the recovery of natural antioxidants from olive mill wastewaters. Chemical Engineering Journal, 198-199, 103-109.

Serra, A. T., Matias, A. A., Almeida, A. P. C., Bronze, M. R., Alves, P. M., de Sousa, H. C., \& Daurte, C. M. M. (2011). Processing cherries (Prunus avium) using supercritical fluid technology. Part 2. Evaluation of SCF extracts as promising nutural chemotherapeutical agents. The Journal of Supercritical Fluids, 55, 1007-1013.

Serra, A. T., Seabra, I. J., Braga, M. E. M., Bronze, M. R., de Sousa, H. C., \& Duarte, C. M. M. (2010). Processing cherries (Prunus avium) using supercritical fluid technology. Part 1: Recovery of extract fractions rich in bioactive compounds. The Journal of Supercritical Fluids, 55, 184-191.

Serradilla, M. J., Martín, A., Ruiz-Moyano, S., Hernández, A., López-Corrales, M., \& Córdoba, M. d. G. (2012). Physicochemical and sensorial characterisation of four sweet cherry cultivars grown in Jerte Valley (Spain). Food Chemistry, 133, 15511559.

Serradilla, M. J., Villalobos, M. d. C., Hernández, A., Martín, A., Lozano, M., \& Córdoba, M. d. G. (2013). Study of microbiological quality of controlled atmosphere packaged 'Ambrunés' sweet cherries and subsequent shelf-life. International Journal of Food Microbiology, 166, 85-92. 
Serrano, M., Díaz-Mula, H.M., Zapata, P.D., Castillo, S., Guillén, F., Martínez-Romero, D., Valverde, J.M. \& Valero, D. (2009). Maturity stage at harvest determines the fruit quality and antioxidant potential after storage of sweet cherry cultivars. Journal of Agricultural and Food Chemistry, 57, 3240-3246.

Serrano, M., Guillén, F., Martínez-Romero, D., Castillo, S., \& Valero, D. (2005). Chemical constituents and antioxidant activity of sweet cherry at different ripening stages. Journal of Agricultural and Food Chemistry, 53, 2741-2745.

Serrano, M., Martínez-Romero, D., Castillo, S., Guillén, F., \& Valero, D. (2005). The use of natural antifungal compounds improves the beneficial effect of MAP in sweet cherry storage. Innovative Food Science \& Emerging Technologies, 6, 115-123.

Sharma, R. R., Singh, D., \& Singh, R. (2009). Biological control of postharvest diseases of fruits and vegetables by microbial antagonists: A review. Biological Control, 50, 205221.

Śliwińska, M., Wiśniewska, P., Dymerski, T., Wardencki, W., \& Namieśnik, J. (2015). The Flavour of fruit spirits and fruit liquers: a review. Flavour and Fragrance Journal, 30, 197-207.

Sredojević, Z., Milić, D., \& Jeločnik, M. (2011). Investment in sweet and sour cherry production and new processing programs in terms of Serbian agriculture competitiveness. Petroleum-Gas University of Ploiesti Bulletin, 62, 37-49.

Sun, S. Y., Jiang, W. G., \& Zhao, Y. P. (2012). Comparison of aromatic and phenolic compounds in cherry wines with different cherry cultivars by HS-SPME-GC-MS and HPLC. International Journal of Food Science \& Technology, 47, 100-106.

Tian, S., Qin, G., \& Xu, Y. (2004). Survival of antagonistic yeasts under field conditions and their biocontrol ability against postharvest diseases of sweet cherry. Postharvest Biology and Technology, 33, 327-331. 
Tian, S.-P., Jiang, A.-L., Xu, Y., \& Wang, Y.-S. (2004). Responses of physiology and quality of sweet cherry fruit to different atmospheres in storage. Food Chemistry, 87, 43-49.

Tomás-Barberán, F. A., \& Andrés-Lacueva, C. (2012). Polyphenols and health: Current state and progress. Journal of Agricultural and Food Chemistry, 60, 8773-8775.

Usenik, V., Fabčič, J., \& Štampar, F. (2008). Sugars, organic acids, phenolic composition and antioxidant activity of sweet cherry (Prunus avium L.). Food Chemistry, 107, 185192.

Usenik, V., Stampar, F., Petkovsek, M. M., \& Kastelec, D. (2015). The effect of fruit size and fruit colour on chemical composition in 'Kordia' sweet cherry (Prunus avium L.). Journal of Food Composition and Analysis, 38, 121-130.

Wang, S., Chen, Y., Xu, Y., Wu, J., Xiao, G., \& Fu, M. (2014). Super atmospheric $\mathrm{O}_{2}$ packaging maintains postharvest quality of cherry (Prunus avium L.) fruit. Journal of Food Processing and Preservation. 38, 2037-2046.

Wang, L. S., \& Stoner, G. D. (2008). Anthocyanins and their role in cancer prevention. Cancer Letters, 269, 281-290.

Wang, L., \& Vestrheim, S. (2002). Controlled atmosphere storage of sweet cherries (Prunus avium L.). Acta Agriculturae Scandinavica, Section B - Soil \& Plant Science, 52, 136142.

Wani, A. A., Singh, P., Gul, K., Wani, M. H., \& Langowski, H. C. (2014). Sweet cherry (Prunus avium): Critical factors affecting the composition and shelf life. Food Packaging and Shelf Life, 1, 86-99.

Webster, A. D., \& Looney N. E. (1996). Cherries: Crop Physiology, Production and Uses. CAB International, Oxon, UK. 
Wen, Y.-Q., He, F., Zhu, B.-Q., Lan, Y.-B., Pan, Q.-H., Li, C.-Y., Reeves, M. J., \& Wang, J. (2014). Free and glycosidically bound aroma compounds in cherry (Prunus avium L.). Food Chemistry, 152, 29-36.

Wilkinson, V. M., \& Gould, G. W. (1998). Food Irradiation: A Reference Guide. Woodhead Publishing: Cambridge.

Xu, X. B., \& Tian, S. P. (2008). Reducing oxidative stress in sweet cherry fruit by Pichia membranaefaciens: a possible mode of action against Penicillium expansum. Journal of Applied Microbiology, 105, 1170-1177.

\section{Figure captions}

Figure 1. Proposed trend for development of processed products from sweet cherries. 
Figure 1

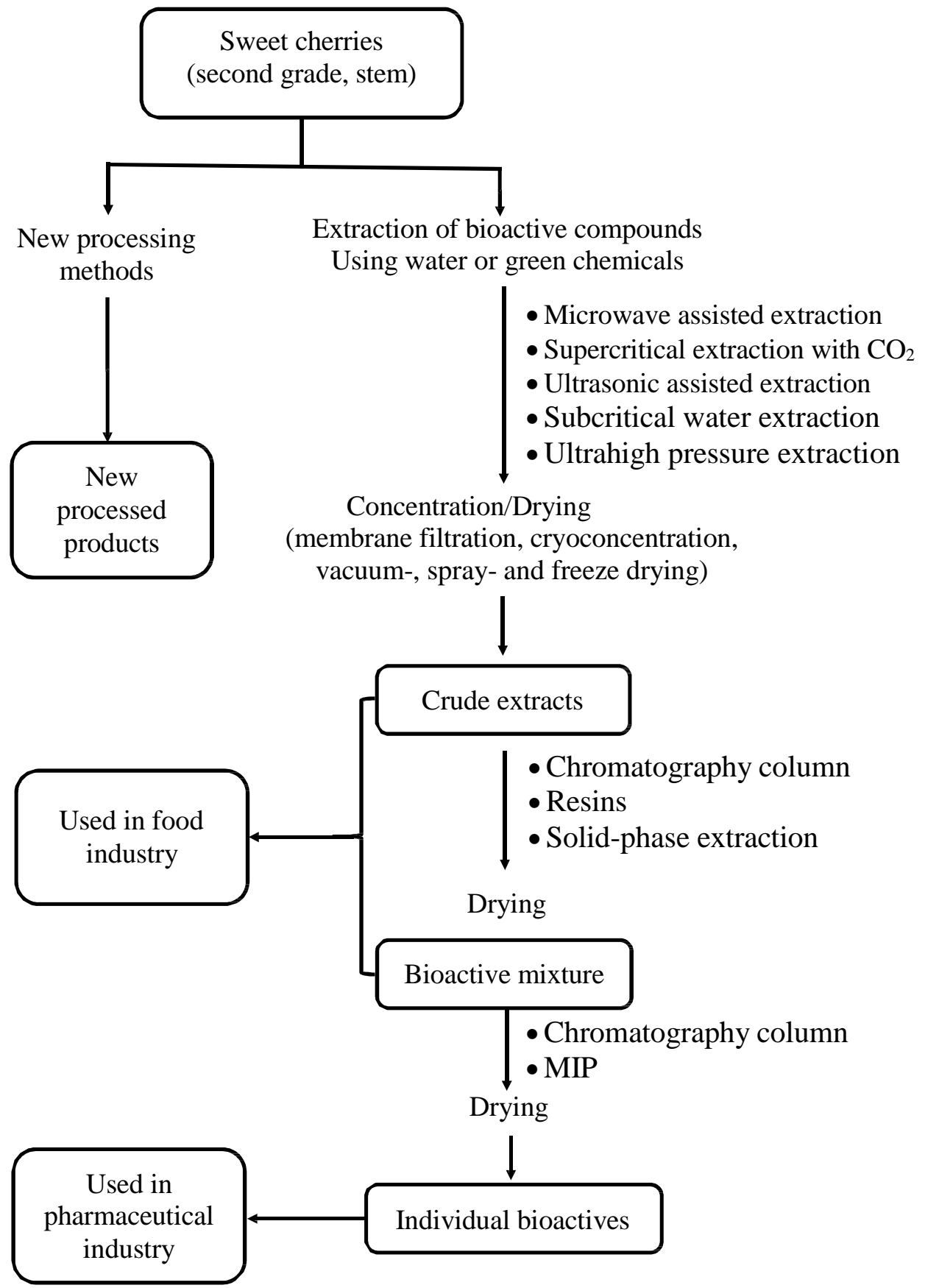


Table 1. Chemical attributes of some sweet cherry cultivars (adapted from Girard \& Kopp (1998); Serrano et al. (2005); Serrano et al. (2009); Serradilla, et al. (2012); Ballistreri, et al. (2013); Hayaloglu \& Demir (2015); Cao, et al. (2015)).

\begin{tabular}{|c|c|c|c|c|c|c|}
\hline Cultivar & $\mathrm{pH}$ & $\begin{array}{c}\text { SSC } \\
\left({ }^{\circ} \text { Brix }\right)\end{array}$ & $\begin{array}{c}\text { TA } \\
\text { (\%malic } \\
\text { acid }) \\
\end{array}$ & SSC/TA & $\begin{array}{c}\text { Total } \\
\text { anthocyanins } \\
(\mathrm{mg} / 100 \mathrm{~g})\end{array}$ & $\begin{array}{c}\text { TPC } \\
(\mathrm{mg} \mathrm{GAE} / 100 \mathrm{~g})\end{array}$ \\
\hline $13 \mathrm{~S}-10-10$ & 3.4 & 18.6 & 1.0 & 18.3 & n.a. & n.a. \\
\hline $13 \mathrm{~S}-20-30$ & 3.8 & 13.6 & 0.6 & 21.6 & n.a. & n.a. \\
\hline $13 \mathrm{~S}-43-48$ & 4.0 & 13.5 & 0.5 & 24.8 & n.a. & n.a. \\
\hline $13 \mathrm{~S}-51-24$ & 3.8 & 16.4 & 0.8 & 21.0 & n.a. & n.a. \\
\hline Ambrunes & 4.4 & 18.0 & 0.5 & 34 & n.a. & 100 \\
\hline Belge & 3.7 & 17.8 & 0.9 & 18.9 & 29.1 & 115.4 \\
\hline Bing & 3.7 & 16.7 & 0.8 & 20.2 & n.a. & n.a. \\
\hline Black pearl & n.a. & 16.9 & 0.6 & 27.7 & 69.8 & 447.0 \\
\hline Black Star & 3.7 & 22.7 & 1.3 & 17.0 & 85.6 & 145.7 \\
\hline Blaze Star & 4.0 & 20.3 & 1.0 & 20.2 & 62.4 & 138.8 \\
\hline Brooks & n.a. & n.a. & 0.9 & n.a. & 10.0 & 70.0 \\
\hline Burlat & 4.2 & 18.4 & 0.8 & 22.2 & 84.6 & 122.0 \\
\hline Comp Stella & 3.9 & 19.7 & 0.8 & 23.3 & n.a. & n.a. \\
\hline Cristalina & n.a. & n.a. & 0.8 & n.a. & 65.0 & 150.0 \\
\hline Dalbasti & 3.7 & 15.2 & 0.7 & 21.0 & 20.4 & 67.5 \\
\hline Donnantonio & 4.4 & 20.7 & 0.7 & 27.6 & 32.8 & 103.8 \\
\hline Ducinola Nera & 4.2 & 22.5 & 1.0 & 22.2 & 40.1 & 149.4 \\
\hline Durona di Cesena & 3.7 & 13.7 & 0.7 & 18.8 & 17.4 & 78.9 \\
\hline Early Star & 4.0 & 15.2 & 1.0 & 15.0 & 47.2 & 87.0 \\
\hline Ferrovia & 4.0 & 19.7 & 0.9 & 22.1 & 27.0 & 97.4 \\
\hline Gabbaladri & 4.3 & 21.5 & 0.7 & 31.5 & 6.2 & 105.3 \\
\hline Genovese & 4.2 & 18.4 & 0.8 & 23.7 & 25.1 & 105.0 \\
\hline Giorgia & 3.9 & 18.9 & 1.0 & 18.2 & 32.5 & 115.0 \\
\hline Grace Star & 3.9 & 17.2 & 0.9 & 18.3 & 27.2 & 114.6 \\
\hline Lambert & 3.7 & 17.2 & 0.9 & 19.9 & n.a. & n.a. \\
\hline Lapins & 3.9 & 16.4 & 0.6 & 25.9 & n.a. & n.a. \\
\hline Maiolina Grappolo & 4.3 & 16.6 & 0.7 & 24.5 & 37.9 & 146.0 \\
\hline Maredda & 4.2 & 19.4 & 0.8 & 24.1 & 94.2 & 162.2 \\
\hline Marvin-Niram & n.a. & n.a. & 1.2 & n.a. & 45.0 & 80.0 \\
\hline Merton Late & 3.7 & 16.1 & 0.7 & 22.2 & 26.2 & 79.3 \\
\hline Minnulara & 4.8 & 21.8 & 0.6 & 37.2 & 27.9 & 124.1 \\
\hline Moreau & 4.2 & 17.6 & 0.8 & 22.2 & 31.5 & 154.5 \\
\hline Napoleana Grappolo & 4.6 & 15.2 & 0.6 & 27.4 & 14.3 & 85.0 \\
\hline Napoleana Verifica & 4.1 & 16.4 & 0.9 & 17.6 & 10.5 & 89.8 \\
\hline Napoleaona Forestiera & 4.3 & 17.3 & 0.9 & 20.1 & 13.3 & 123.6 \\
\hline Newstar & n.a. & n.a. & 1.2 & n.a. & 25.0 & 75.0 \\
\hline No.57 & n.a. & n.a. & 1.0 & n.a. & 20.0 & 70.0 \\
\hline NY-6479 & n.a. & n.a. & 1.3 & n.a. & 15.0 & 80.0 \\
\hline Pico Colorado & 4.2 & 20.0 & 0.6 & 39.0 & n.a. & 50.0 \\
\hline Pico Negro & 4.3 & 15.0 & 0.6 & 25.0 & n.a. & 150.0 \\
\hline Prime Giant & n.a. & n.a. & 1.0 & n.a. & 15.0 & 80.0 \\
\hline Puntalazzese & 4.1 & 22.3 & 1.3 & 16.7 & 58.3 & 156.0 \\
\hline Salmo & 3.8 & 24.5 & 0.8 & 29.0 & n.a. & n.a. \\
\hline Santina & n.a. & 16.5 & 0.6 & 26.7 & 98.1 & 687.4 \\
\hline Somerset & n.a. & n.a. & 0.9 & n.a. & 25.0 & 80.0 \\
\hline Sonata & n.a. & n.a. & 1.3 & n.a. & 130.0 & 100.0 \\
\hline Starks Gold & 3.7 & 14.1 & 0.8 & 18.6 & 0.6 & 64.4 \\
\hline Summit & 4.0 & 19.6 & 0.7 & 28.6 & n.a. & n.a. \\
\hline Sunburst & 3.9 & 19.7 & 0.9 & 21.7 & 24.7 & 102.8 \\
\hline Sweet Early & 3.9 & 13.5 & 0.8 & 17.8 & 70.6 & 110.8 \\
\hline
\end{tabular}




\begin{tabular}{|l|c|c|c|c|c|c|}
\hline Sweetheart & 3.9 & 20.8 & 0.9 & 22.2 & 28.1 & 89.6 \\
\hline Toscana & 4.2 & 19.5 & 0.9 & 20.9 & 29.0 & 131.7 \\
\hline Van & 3.5 & 17.9 & 0.9 & 19.9 & n.a. & n.a. \\
\hline Vista & 3.6 & 15.2 & 0.8 & 18.7 & 14.8 & 61.1 \\
\hline Zio Peppino & 4.1 & 13.7 & 0.7 & 19.1 & 7.6 & 86.1 \\
\hline 0-900 Ziraat & 3.8 & 16.6 & 0.8 & 20.9 & 24.6 & 69.7 \\
\hline
\end{tabular}

n.a., not available. 
Table 2. Phenolics and anthocyanins (mg/100g fresh weight) in various sweet cheery cultivars (adapted from Gao \& Mazza (1995); ; González-Gómez, et al. (2010); Kim, et al. (2005); Usenik, et al. (2008); Serradilla et al. (2013); Hayaloglu \& Demir (2016)).

\begin{tabular}{|c|c|c|c|c|c|c|c|c|c|c|c|}
\hline \multirow[t]{2}{*}{ Cultivars } & \multicolumn{3}{|c|}{ Hydroxycinnamic acids } & \multicolumn{5}{|c|}{ Anthocyanins } & \multirow{2}{*}{$\begin{array}{c}\text { Flavonol } \\
\text { Rutin }\end{array}$} & \multirow{2}{*}{$\begin{array}{c}\text { Flavan-3-ols } \\
\text { Epicatechin }\end{array}$} & \multirow{2}{*}{$\begin{array}{l}\text { Method of } \\
\text { detection }\end{array}$} \\
\hline & $\begin{array}{c}\text { Neochloro- } \\
\text { genic }\end{array}$ & $\begin{array}{c}\text { p-Coumaroyl- } \\
\text { quinic }\end{array}$ & $\begin{array}{l}\text { Chloro- } \\
\text { genic }\end{array}$ & $\begin{array}{c}\text { Cy-3- } \\
\text { glucoside }\end{array}$ & $\begin{array}{c}\mathrm{Cy}-3- \\
\text { rutinoside }\end{array}$ & $\begin{array}{c}\text { Peonidin-3- } \\
\text { glucoside }\end{array}$ & $\begin{array}{c}\text { Pelargonidin- } \\
\text { 3-rutinoside }\end{array}$ & $\begin{array}{c}\text { Peonidin-3- } \\
\text { rutinoside }\end{array}$ & & & \\
\hline Bing & 128.2 & 42.7 & n.a. & 31.1 & 180.6 & 0.8 & 3.1 & 9.2 & n.a. & n.a. & \multirow[t]{7}{*}{ HPLC } \\
\hline Lambert & 118.9 & 47.0 & n.a. & 44.1 & 150.5 & 0.7 & 0.7 & 2.4 & n.a. & n.a. & \\
\hline Sam & 38.4 & 131.4 & n.a. & 24.8 & 193.3 & 0.6 & 1.9 & 6.5 & n.a. & n.a. & \\
\hline Stella & 92.9 & 32.5 & n.a. & 18.2 & 128.7 & 0.3 & 0.7 & 6.3 & n.a. & n.a. & \\
\hline Summit & 29.0 & 84.0 & n.a. & 6.3 & 72.2 & 0.3 & 0.6 & 2.6 & n.a. & n.a. & \\
\hline Sylvia & 34.2 & 76.3 & n.a. & 15.3 & 211.1 & 0.6 & 2.1 & 15.8 & n.a. & n.a. & \\
\hline Van & 87.5 & 23.0 & n.a. & 12.0 & 130.2 & 0.5 & 0.7 & 7.4 & n.a. & n.a. & \\
\hline Hartland & 8.8 & 6.8 & 0.6 & 12.1 & 74.7 & n.a. & n.a & 5.8 & 4.7 & n.a & \multirow[t]{4}{*}{ HPLC } \\
\hline Hedelfingen & 10.2 & 1.0 & 0.2 & 6.0 & 34.4 & n.a. & n.a & 0.8 & 2.0 & n.a & \\
\hline Regina & 6.7 & 3.8 & 0.5 & 3.7 & 40.4 & n.a. & n.a & 2.7 & 2.8 & n.a & \\
\hline Black Gold & 2.9 & 3.6 & 0.1 & 2.3 & 26.8 & n.a. & n.a & 1.9 & 1.1 & n.a & \\
\hline Badascony & 4.7 & 4.2 & 1.1 & 0.6 & 12.8 & n.a. & 0.2 & 0.2 & 5.8 & 2.0 & \multirow{13}{*}{$\begin{array}{l}\text { HPLC- } \\
\text { DAD/MS }\end{array}$} \\
\hline Burlat & 6.8 & 6.4 & 1.1 & 2.3 & 8.28 & n.a. & 0.2 & 0.1 & 4.5 & 3.1 & \\
\hline $\begin{array}{l}\text { Early Van } \\
\text { Compact }\end{array}$ & 11.9 & 1.2 & 2.3 & 0.2 & 8.06 & n.a. & 0.8 & 0.2 & 3.5 & 1.3 & \\
\hline Fercer & 5.8 & 5.2 & 1.0 & 0.5 & 8.9 & n.a. & 0.4 & 0.2 & 4.5 & 3.0 & \\
\hline Fernier & 8.7 & 1.2 & 2.6 & 1.0 & 14.8 & n.a. & 0.2 & 0.2 & 3.8 & 1.0 & \\
\hline Ferprime & 8.7 & 6.3 & 0.6 & 1.8 & 7.4 & n.a. & 0.4 & 0.1 & 2.8 & 4.5 & \\
\hline Ferrador & 8.5 & 1.3 & 1.2 & 0.0 & 1.1 & n.a. & 0.0 & 0.0 & 2.7 & 0.8 & \\
\hline Lala Star & 10.6 & 1.7 & 2.5 & 0.6 & 11.2 & n.a. & 1.1 & 0.2 & 4.4 & 1.0 & \\
\hline Lapins & 8.7 & 0.8 & 1.7 & 0.1 & 3.1 & n.a. & 0.3 & 0.0 & 2.1 & 0.4 & \\
\hline $\begin{array}{l}\text { Noire de } \\
\text { Meched }\end{array}$ & 6.8 & 6.1 & 0.6 & 0.6 & 9.4 & n.a. & 0.9 & 0.2 & 5.0 & 0.8 & \\
\hline Sylvia & 7.3 & 7.2 & 0.8 & 0.3 & 9.8 & n.a. & 0.4 & 0.1 & 3.7 & 2.9 & \\
\hline Vesseaux & 8.3 & 2.1 & 2.3 & 0.8 & 13.1 & n.a. & 0.4 & 0.2 & 4.0 & 1.2 & \\
\hline Vigred & 6.5 & 5.0 & 1.1 & 0.9 & 13.5 & n.a. & 0.7 & 0.3 & 5.7 & 3.7 & \\
\hline Navalinda & 37.4 & 89.7 & 1.0 & 21.2 & 100.0 & n.a. & n.a & 1.5 & 4.1 & 13.4 & \multirow{5}{*}{$\begin{array}{l}\text { HPLC- } \\
\text { DAD/MS }\end{array}$} \\
\hline $\begin{array}{l}\text { Pico Nero } \\
\text { Limón }\end{array}$ & 55.6 & 62.2 & 1.0 & 3.5 & 10.7 & n.a. & n.a & 1.1 & 2.6 & 7.8 & \\
\hline Ambrunés & 51.8 & 60.5 & 0.8 & 3.4 & 65.8 & n.a. & n.a & 0.7 & 4.3 & 5.8 & \\
\hline Pico Negro & 74.1 & 130.0 & 5.7 & 4.4 & 105.0 & n.a. & n.a & 3.9 & 5.5 & 9.1 & \\
\hline Pico colorado & 81.3 & 89.3 & 11.9 & 2.9 & 25.9 & & & 0.1 & 4.3 & 12.2 & \\
\hline Ambrunes & 38.5 & 45.8 & 2.0 & 1.9 & 51.8 & 0.3 & n.a. & n.a. & 5.1 & 1.6 & HPLC \\
\hline Belge & 24.0 & 49.6 & 2.0 & 7.1 & 53.0 & 0.4 & 0.4 & 0.9 & 2.5 & 7.7 & \multirow[t]{3}{*}{ HPLC } \\
\hline Bing & 146.6 & 37.0 & 4.4 & 8.0 & 23.6 & 0.4 & 0.2 & 0.8 & 2.8 & 12.8 & \\
\hline Dalbasti & 40.1 & 88.6 & 2.4 & 2.5 & 19.8 & 0.3 & 0.1 & 0.1 & 1.5 & 7.2 & \\
\hline
\end{tabular}




\begin{tabular}{|l|c|c|c|c|c|c|c|c|c|c|c|c|}
\hline $\begin{array}{l}\text { Durona di } \\
\text { Cesena }\end{array}$ & 128.8 & 32.6 & 2.6 & 1.9 & 14.6 & 0.3 & n.d. & 0.2 & 1.8 & 14.7 & & \\
\hline Lambert & 145.0 & 42.0 & 5.1 & 1.9 & 13.9 & 0.4 & 0.1 & 0.2 & 1.3 & 9.0 \\
\hline Merton Late & 50.4 & 87.1 & 3.5 & 3.6 & 25.8 & 0.3 & 0.1 & 0.2 & 3.1 & 13.4 \\
\hline Starks Gold & 113.5 & 33.1 & 3.2 & n.a. & n.a. & n.a. & n.a. & n.a. & 1.7 & 7.7 \\
\hline Summit & 35.2 & 98.7 & 3.5 & 2.5 & 21.6 & 0.3 & 0.2 & 0.3 & 1.4 & 8.1 \\
\hline Sweetheart & 41.3 & 64.3 & 2.5 & 1.7 & 17.9 & 0.4 & 0.1 & 0.4 & 2.2 & 6.2 \\
\hline Van & 71.5 & 17.3 & 3.1 & 2.8 & 20.2 & 0.3 & 0.1 & 0.6 & 1.9 & \\
\hline Vista & 120.3 & 31.3 & 2.6 & 2.1 & 11.9 & 0.3 & n.d. & 0.2 & 2.0 & 12.5 \\
\hline 0-900 Ziraat & 43.3 & 70.5 & 3.0 & 3.1 & 25.0 & 0.3 & n.d. & 0.2 & 2.5 & 8.3 \\
\hline
\end{tabular}

n.a., not available.

n.d., not detected. 